\title{
HUBUNGAN ANTARA LESI PRAKANKER SERVIKS DENGAN SOSIODEMOGRAFI PEREMPUAN DI KECAMATAN LEGOK KABUPATEN TANGERANG TAHUN 2018
}

\author{
Destiyana Cika Claritha ${ }^{1}$, Chandra Dewi K. S. ${ }^{2}$, Shintia Christina ${ }^{3}$ \\ ${ }^{1}$ Fakultas Kedokteran Universitas Kristen Krida Wacana, Jakarta \\ Email: destiyana.2015fk092@civitas.ukrida.ac.id \\ ${ }^{2}$ Laboratorium Patologi Anatomi, Rumah Sakit Umum Daerah Tarakan, Jakarta \\ ${ }^{3}$ Departemen Patologi Anatomi, Fakultas Kedokteran Universitas Kristen Krida Wacana, Jakarta Barat
}

Masuk: 10-12-2019, revisi: 01-03-2020, diterima untuk diterbitkan: 04-06-2020

\begin{abstract}
ABSTRAK
Penyakit kanker serviks dan payudara merupakan penyakit kanker dengan prevalensi tertinggi di Indonesia pada tahun 2013 yang menyebabkan kematian pada perempuan Indonesia, yaitu kanker serviks sebesar $0,8 \%$ dan kanker payudara sebesar $0,5 \%$. Lesi prakanker pada serviks dikenal juga dengan sebutan lesi intraepitelial serviks (Cervical Intraephitelial Neoplasia) merupakan awal dari perubahan menuju karsinoma serviks. Pada umumnya lesi prakanker serviks ini berawal dari daerah squamocolumnar junction pada serviks uteri yang mengalami proses metaplasia. Penelitian ini bertujuan untuk mengetahui adakah hubungan antara lesi prakanker serviks dengn sosiodemografi perempuan di Kecamatan Legok Kabupaten Tangerang tahun 2018. Penelitian ini merupakan studi analitik dengan pendekatan cross sectionaI. Populasi penelitian adalah semua perempuan di Kecamatan Legok Kabupaten Tangerang yang sudah berhubungan seksual. Total sampel 47 orang.
\end{abstract}

Kata Kunci: kanker serviks; lesi prakanker serviks; paritas

\begin{abstract}
Cervical and breast cancer are the highest prevalence cancer in Indonesia in 2013 which caused death to Indonesian women, cervical cancer by $0.8 \%$ and breast cancer by $0.5 \%$. Precancerous lesions of the cervix also known as cervical intraepithelial lesions (Cervical Intraepithelial Neoplastic) are the beginning of changes to cervical carcinoma. In general, precancerous lesions of the cervix originate from the squamous columnar junction in the uterine cervix, which undergoes the process of metaplasia. This study aims to determine whether there is a relationship between precancerous cervical lesions and sociodemography of women in Kecamatan Legok Kabupaten Tangerang in 2018. This study uses an analytical study with cross sectionaI approach. The population is all women in Kecamatan Legok Kabupaten Tangerang who had sexual relations. Total sample are 47 people.
\end{abstract}

Keywords: cervical cancer; cervical precancerous lesions; parity

\section{PENDAHULUAN}

\section{Latar Belakang}

Lesi prakanker pada serviks dikenal juga dengan sebutan lesi intraepitelial serviks (Cervical Intraephitelial Neoplasia) merupakan awal dari perubahan menuju karsinoma serviks. Pada umumnya lesi prakanker serviks ini berawal dari daerah squamocolumnar junction pada serviks uteri yang mengalami proses metaplasia. Proses metaplasia ini paling aktif terjadi pada masa setelah menarche dan setelah proses kehamilan, sehingga lesi prakanker banyak didapatkan pada masa-masa ini. Daerah squamocolumnar junction yang mengalami proses metaplasia ini akan lebih rentan terpapar oleh faktor-faktor risiko terjadinya suatu lesi prakanker. (Kusuma, 2015)

Penyakit kanker merupakan salah satu penyebab kematian utama di seluruh dunia. Berdasarkan GLOBOCAN 2012 kanker serviks menduduki urutan ke-7 secara global dalam segi angka 
kejadian (urutan ke-6 dinegara berkembang), sedangkan menurut Kementerian Kesehatan RI tahun 2012, sekitar 8,2 juta kematian disebabkan oleh kanker. Secara nasional prevalensi penyakit kanker pada penduduk semua umur di Indonesia tahun 2013 sebesar 1,4\%o atau diperkirakan sekitar 347.792 orang. Penyakit kanker serviks dan payudara merupakan penyakit kanker dengan prevalensi tertinggi di Indonesia pada tahun 2013 yang menyebabkan kematian pada perempuan Indonesia, yaitu kanker serviks sebesar 0,8\% dan kanker payudara sebesar 0,5\%o. Provinsi DKI Jakarta memiliki prevalensi kanker serviks 1,2\% dan Provinsi Banten memiliki prevalensi 0,4\%. Berdasarkan estimasi jumlah penderita kanker serviks dan kanker payudara terbanyak terdapat pada Provinsi Jawa Timur dan Provinsi Jawa Tengah. (PDI Kemenkes, 2015)

Adanya keterbatasan sumber daya, sarana, dan prasarana berperan juga dalam menentukan peningkatan kematian akibat kanker tersebut. Hal ini disebabkan karena kurangnya kesadaran dalam melakukan deteksi dini dan penatalaksanaan yang adekuat bila dijumpai adanya kelainan pada serviks. Berbagai upaya pencegahan meliputi identifikasi dan mencegah faktor risiko, deteksi dini lesi prakanker, dan termasuk pula temuan baru berupa vaksinasi HPV. Deteksi dini telah dilakukan untuk menemukan lesi prakanker. Upaya-upaya yang dilakukan berupa tes pap smear, inspeksi visual dengan asam asetat (IVA) dan lain sebagainya. (Rasjidi, 2008)

Antara ketiga komponen (pejamu, agen dan lingkungan) terdapat keseimbangan yang disebut keseimbangan ekologi. Timbulnya penyakit ini disebabkan karena ketidakseimbangan ketiga komponen tersebut dimana komponen agennya adalah HPV, hostnya berupa faktor risiko seperti umur, usia saat pertama kali berhubungan seksual, paritas dan riwayat penyakit menular seksual. Sedangkan faktor lingkungan yang berpengaruh adalah riwayat penggunaan kontrasepsi hormonal dan personal higiene. Pemilihan kontrasepsi dan perilaku personal higiene ditentukan oleh pendidikan, pengetahuan dan pengaruh dari masyarakat, tenaga medis dan keluarga. (Koswara, 2016)

Berdasarkan uraian di atas serta didukung penelitian-penelitian sebelumnya, maka peneliti tertarik untuk melakukan penelitian mengenai hubungan antara lesi prakanker serviks dengan sosiodemografi perempuan yang dalam penelitian kali ini berlokasi di Kecamatan Legok Kabupaten Tangerang. Adapun tujuan penelitian adalah dapat membantu masyarakat tersebut untuk mengetahui dan memahami serta sebagai evaluasi diri sebagai pencegahan dini berdasarkan faktor sosiodemografi (umur, aktivitas seksual, dan paritas), dan sosio ekonomi (pekerjaan dan pendidikan).

\section{Rumusan masalah}

Berdasarkan latar belakang diatas maka peneliti ingin mengetahui bagaimana hubungan antara lesi prakanker serviks dengan sosiodemografi pada perempuan di Kecamatan Legok Kabupaten Tangerang tahun 2018.

\section{METODE PENELITIAN}

Penelitian dilakukan di Vihara Cetiya Dharma Dvipa, Kecamatan Legok, Kabupaten Tangerang pada bulan Agustus - September 2018. Penelitian ini merupakan studi analitik dengan pendekatan cross sectional untuk mengetahui hubungan lesi prakanker serviks terhadap 
sosiodemografi pada saat yang bersamaan pada perempuan di Kecamatan Legok Kabupaten Tangerang. Populasi target pada penelitian ini adalah seluruh perempuan di wilayah Tangerang yang sudah berhubungan seksual. Populasi terjangkau penelitian ini adalah perempuan di Kecamatan Legok Kabupaten Tangerang Tahun 2018 yang sudah berhubungan seksual.

Sampel yang digunakan pada penelitian ini adalah consecutive sampling, perempuan yang tinggal diwilayah Kecamatan Legok Kabupaten Tangerang dan memenuhi kriteria pemilihan dimasukkan dalam penelitian sampai jumlah subyek yang diperlukan terpenuhi. Jumlah sampel yang direncanakan berdasarkan perhitungan sampel adalah 48. Pada penelitian ini jumlah sampel yang didapat adalah 47, dimana hal tersebut hampir mencapai target. Analisis data menggunakan teknik bivariat uji statiska Chi Square untuk mengetahui hubungan antara variabel dependen dan variabel independen.

\section{HASIL DAN PEMBAHASAN}

\section{Karakteristik responden}

Karakteristik demografis yang diamati pada penelitian ini meliputi usia, paritas, serta aktivitas seksual. Pada penelitian ini dilakukan pembagian berdasarkan kelompok pertama adalah berdasarkan usia yaitu 21-30 tahun, 31- 40 tahun, 41-50 tahun dan 51-60 tahun, dimana paling banyak responden yang melakukan pemeriksaan IVA dan Pap Smear di Kecamatan Legok berada dikelompok usia 21 - 30 tahun sebanyak 18 orang (38,3\%). Usia $31-40$ tahun sebanyak 13 orang $(27,7 \%)$, usia 41 - 50 tahun sebanyak 12 orang $(25,5 \%)$ dan paling sedikit berada direntang usia $51-60$ tahun ada 4 orang $(8,5 \%)$.

Kelompok kedua adalah paritas yaitu jumlah anak yang dilahirkan baik yang hidup maupun meninggal dunia oleh wanita yang melakukan pemeriksaan IVA. Sebagian besar responden memiliki jumlah anak 2 orang sebanyak 17 orang (36,1\%) kemudian memiliki 3 anak ada 11 orang $(23,4 \%)$. Responden yang memiliki 1 dan $\geq 4$ anak masing-masing 9 orang $(19,2 \%)$ dan ada 1 responden $(2,1 \%)$ yang belum pernah melahirkan. Kelompok ketiga berdasarkan aktivitas seksual hampir semua responden hanya memiliki satu pasangan seks selama hidupnya hingga pemeriksaan IVA dan Pap Smear dilakukan pada tahun 2018. Sebagian besar responden banyak melakukan aktivitas seksual bersama pasangannya tiap 2-3x seminggu ada 25 orang $(53,2 \%)$. Adapun 10 responden $(21,2 \%)$ melakukannya tiap $1 \mathrm{x}$ seminggu, 6 orang $(12,8 \%)$ tiap $1 \mathrm{x}$ sebulan, 3 orang $(6,4 \%)$ tiap $3 x$ sebulan dan ada 2 orang $(6,4 \%)$ yang janda dan tidak melakukan koitus lagi.

Karakteristik sosioekonomi yang diamati pada penelitian ini meliputi pendidikan dan pekerjaan. Kelompok ke empat yaitu pendidikan dibagi menjadi pendidkan tinggi yaitu SMA/Sederajat dan pendidikan rendah yaitu SD dan SMP. Pendidikan responden lebih besar pada SMA/SMK yakni 23 orang $(48,9 \%)$. Untuk pendidikan SMP sebanyak 14 orang (29,8\%), SD sebanyak 9 orang $(19,2 \%)$ dan yang paling sedikit lulusan D III hanya 1 orang $(2,1 \%)$. Kelompok ke lima yaitu pekerjaan dibagi menjadi IRT dan Non IRT. Terlihat bahwa responden lebih banyak yang tidak bekerja, jadi hanya sebagai ibu rumah tangga sebanyak 42 orang $(89,4 \%)$. Responden yang bekerja hanya sebagain kecil saja, dengan perincian sebagai berikut: karyawati sebanyak 3 orang $(6,4 \%)$, pedagang dan penjahit masing-masing 1 orang $(2,1 \%)$. 
Tabel 1.Karateristik Responden

\begin{tabular}{|c|c|c|c|}
\hline & Variabel Sosiodemografi & $\mathrm{N}(47)$ & $\%$ \\
\hline \multirow[t]{3}{*}{1} & Usia & & \\
\hline & $<40$ tahun & 30 & 64 \\
\hline & $\geq 40$ tahun & 17 & 36 \\
\hline \multirow[t]{5}{*}{2} & Paritas & & \\
\hline & $\leq 2$ anak & 27 & 57 \\
\hline & $>2$ anak & 20 & 43 \\
\hline & $<2$ anak & 10 & 21 \\
\hline & $\geq 2$ anak & 37 & 79 \\
\hline \multirow[t]{4}{*}{3} & Aktivitas seksual & & \\
\hline & $\leq 7$ hari & 35 & 74 \\
\hline & $>7$ hari & 12 & 26 \\
\hline & Variabel Sosioekonomi & $\mathrm{N}(47)$ & $\%$ \\
\hline \multirow[t]{3}{*}{4} & Pendidikan & & \\
\hline & Tinggi & 24 & 51 \\
\hline & Rendah & 23 & 49 \\
\hline \multirow[t]{3}{*}{5} & Pekerjaan & & \\
\hline & Non IRT & 5 & 11 \\
\hline & IRT & 42 & 89 \\
\hline
\end{tabular}

Untuk mengetahui hubungan antara variabel independen dengan variabel dependen dilakukan analisis bivariat dengan Chi square karena baik pada variabel independen, maupun variabel dependen merupakan data kategorik. Variabel independen dikatakan mempunyai hubungan dengan variabel dependen bila nilai $p$ value $\leq 0,05$. Jika ada sel yang mempunyai nilai harapan lebih kecil dari 1 dan atau ada 20\% sel yang mempunyai nilai harapan lebih kecil dari 5, maka digunakan uji fisher exact. Untuk melihat kekuatan hubungannya dengan cara melihat nilai OR

Hasil analisis bivariat antara usia dengan kejadian lesi prakanker serviks tidak bermakna secara spesifik karena nilai-p yang diperoleh adalah 1,000 (nilai-p $>\alpha$ ). Dalam penelitian ini, usia dikelompokkan menjadi $\geq 40$ tahun dan $<40$ tahun. Namun, OR yang dihasilkan memiliki interval kepercayaan yang lebar, sehingga memungkinkan adanya hubungan antara variabel independen dan dependen. Perempuan yang berusia $\geq 40$ tahun memiliki risiko $1,20(95 \% \mathrm{CI}$ 0,180-8,001) kali untuk mengalami kejadian lesi prakanker dibandingkan dengan perempuan yang berusia $<40$ tahun.

Hubungan antara kejadian lesi prakanker serviks dengan paritas tidak bermakna secara statistik karena nilai-p yang diperoleh lebih besar dari nilai $\alpha=0,05$ (nilai-p $=0,638$ ). Dalam penelitian ini, paritas dikelompokkan menjadi perempuan yang memiliki $\leq 2$ anak dan $>2$ anak. Didapatkan risiko perempuan yang memiliki > 2 anak untuk mengalami kejadian lesi prakanker cukup besar yaitu 2,206 (95\% CI 0,332-14,635) kali dibandingkan dengan perempuan yang memiliki $\leq 2$ anak. Sedangkan pada paritas yang dikelompokkan menjadi perempuan yang memiliki $<2$ anak dan $\geq 2$ anak didapatkan penurunan nilai-p menjadi 0,28.

Hasil analisis bivariat antara aktivitas seksual dengan kejadian lesi prakanker serviks tidak bermakna secara statistik karena nilai-p yang diperoleh adalah 1,000 (nilai-p $>\alpha$ ). Pasangan 
yang melakukan hubungan seksual $\leq 7$ hari memiliki risiko $1,419(95 \%$ CI $0,143-14,111)$ untuk mengalami kejadian lesi prakanker dibandingkan dengan perempuan yang berusia $>7$ hari.

Secara statistik antara pendidikan dengan kejadian lesi prakanker serviks tidak ada hubungan yang bermakna karena nilai $p$-value yang didapat 1,000 (nilai-p $>\alpha$ ). Dalam penelitian ini, pendidikan dikelompokkan menjadi pendidikan tinggi ( $\geq \mathrm{SMA} /$ sederajat.) dan pendidikan rendah (SD dan SMP). Walaupun gagal dibuktikan ada hubungan antara pendidikan dengan kejadian lesi prakanker serviks, tapi dari nilai OR 0,667 (95\% CI 1,101-4,407) dapat disimpulkan bahwa perempuan yang mempunyai pendidikan < SMA/sederajat cenderung memiliki risiko 0,667 untuk terjadi lesi prakanker serviks dibandingkan perempuan yang memiliki pendidikan akhir $\geq$ SMA/sederajat.

Untuk pekerjaan dikategorikan menjadi IRT dan non IRT, berdasarkan analisis bivariat didapatkan nilai $p$-value 0,445 (nilai-p $>\alpha$ ). Ini berarti tidak ada hubungan yang bermakna antara pekerjaan dengan kejadian lesi prakanker serviks. Bila dilihat dari odd ratio-nya perempuan yang bekerja cenderung lebih rendah untuk terjadinya lesi prakanker serviks dibandingkan dengan perempuan yang tidak bekerja, karena OR yang didapat 0,421 (95\% CI 0,037-4,742).

\section{Hubungan antara Variabel Independen dan Variabel Dependen Usia dengan kejadian lesi prakanker serviks}

HPV ditransmisikan melalui hubungan seksual. Oleh karena itu, usia yang rentan terkena infeksi HPV adalah umur reproduksi, yaitu umur kurang dari 50 tahun. Pola prevalensi infeksi HPV menurut umur berbeda-beda tiap negara. Penelitian di Sub-Sahara menemukan bahwa prevalens HPV menurun seiring bertambahnya usia, sedangkan di Cina prevalens meningkat pada usia 30 sampai 44 tahun kemudian menurun pada usia di atasnya Menurut Li et al, wanita yang berusia $<50$ tahun lebih berisiko untuk terinfeksi HPV dibandingkan dengan yang berusia $\geq$ 50 tahun. (Susilawati, 2012)

Tabel 2. Hubungan antara Faktor-Faktor yang Mempengaruhi Kejadian Lesi Prakanker Serviks di Kecamatan Legok, Kabupaten Tangerang Tahun 2018

\begin{tabular}{|c|c|c|c|c|c|c|c|c|}
\hline \multirow[t]{2}{*}{ No } & \multirow{2}{*}{ Variabel } & \multicolumn{4}{|c|}{ Kejadian Lesi Prakanker } & \multirow{2}{*}{ OR } & \multirow{2}{*}{$95 \%$ CI } & \multirow[t]{2}{*}{ p-value } \\
\hline & & Positif & $\%$ & Negatif & $\%$ & & & \\
\hline \multirow[t]{3}{*}{1} & Usia & & & & & & & \\
\hline & $<40$ tahun & 3 & 10 & 27 & 90 & \multirow{2}{*}{1,200} & \multirow{2}{*}{$\begin{array}{l}0,180- \\
8,001\end{array}$} & \multirow[t]{2}{*}{1,000} \\
\hline & $\geq 40$ tahun & 2 & 11,8 & 15 & 88,2 & & & \\
\hline \multirow[t]{5}{*}{2} & Paritas & & & & & & & \\
\hline & $\leq 2$ anak & 2 & 7,4 & 25 & 92,6 & \multirow{2}{*}{2,206} & \multirow{2}{*}{$\begin{array}{l}0,332- \\
14,635 \\
\end{array}$} & \multirow[t]{2}{*}{0,638} \\
\hline & $>2$ anak & 3 & 15 & 17 & 85 & & & \\
\hline & $<2$ anak & 2 & 20 & 8 & 80 & \multirow{2}{*}{0,353} & $0,050-$ & \multirow{2}{*}{0,285} \\
\hline & $\geq 2$ anak & 3 & 8,1 & 34 & 91,9 & & 2,476 & \\
\hline \multirow[t]{3}{*}{3} & Aktivitas seksual & & & & & & & \\
\hline & $\leq 7$ hari & 4 & 11,4 & 31 & 88,6 & \multirow{2}{*}{1,419} & \multirow{2}{*}{$\begin{array}{l}0,143- \\
14,111\end{array}$} & \multirow[t]{2}{*}{1,000} \\
\hline & $>7$ hari & 1 & 8,3 & 11 & 91,7 & & & \\
\hline \multirow[t]{3}{*}{4} & Pendidikan & & & & & & & \\
\hline & Tinggi & 3 & 12,5 & 21 & 87,5 & \multirow{2}{*}{0,667} & \multirow{2}{*}{$\begin{array}{l}1,101- \\
4,407\end{array}$} & \multirow[t]{2}{*}{1,000} \\
\hline & Rendah & 2 & 8,7 & 21 & 91,3 & & & \\
\hline \multirow[t]{3}{*}{5} & Pekerjaan & & & & & & & \\
\hline & Non IRT & 1 & 20 & 4 & 80 & \multirow{2}{*}{0,421} & \multirow{2}{*}{$\begin{array}{l}0,037- \\
4,742\end{array}$} & 0,445 \\
\hline & IRT & 4 & 9,5 & 38 & 90,5 & & & \\
\hline
\end{tabular}


Secara statistik didapatkan tidak adanya hubungan antara usia dengan kejadian lesi prakanker serviks. Hasil penelitian ini menemukan bahwa wanita yang berusia $\geq 40$ tahun saat pemeriksaan IVA memiliki risiko 1,2 kali untuk menderita lesi prakanker leher rahim dibandingkan dengan wanita yang berusia < 40 tahun. Berdasarkan hasil penelitian dari dokter Sofia (2015) di RSUD Tugurejo menemukan hal yang serupa, yakni hubungan antara usia dan kejadian lesi prakanker serviks tidak bermakna dan wanita yang berusia $\geq 40$ tahun tahun berisiko 4,9 kali untuk mengalami lesi prakanker dibandingkan wanita yang berusia $<40$ tahun.

Ditinjau dari usia pertama hubungan seksual wanita yang aktif secara seksual sejak usia muda akan meningkatkan risiko kanker serviks. Risiko kanker serviks meningkat pada wanita yang pertama kali melakukan hubungan seksual kurang dari umur 20 tahun. Umur yang dianggap optimal untuk reproduksi antara 20 - 35 tahun yang disebut juga masa reproduktif. Umur $15-20$ tahun merupakan periode yang rentan. (Nelli, 2017)

Penelitian Louie dkk. menyatakan bahwa usia terlalu muda saat pertama kali berhubungan seks menjadi faktor risiko kanker serviks di 8 negara berkembang. Wanita yang melakukan hubungan seksual pertama kali pada usia 17-20 tahun berisiko 1,80 kali untuk terkena kanker serviks, sedangkan wanita yang yang melakukan hubungan seks pertama kali pada usia $\leq 16$ tahun lebih berisiko 2,31 kali untuk terkena kanker serviks. (Ningsih, 2017)

Ketidakmatangan serviks secara biologis pada usia muda dapat menjadi faktor risiko penting untuk terjadinya kanker serviks. Infeksi pertama serviks terhadap HPV sering terjadi setelah terjadinya hubungan seks yang pertama sehingga risiko kerentanan serviks yang belum matang terhadap infeksi HPV akan meningkat. Wanita yang mulai melakukan hubungan seksual pada usia $<20$ tahun lebih berisiko karena pada periode dewasa muda proses metaplasia sel skuamosa sangat meningkat sehingga risiko terjadinya transformasi atipik skuamosa meningkat yang kemudian menjadi neolpasia intraepitel cerviks (CIN). (Ningsih, 2017)

\section{Paritas dengan kejadian lesi prakanker serviks}

Kaitan tingginya paritas dengan kejadian kanker leher rahim adalah semakin banyak anak yang dilahirkan oleh seorang wanita, maka semakin sering pula serviksnya mengalami infeksi, infeksi pada serviks tersebut mungkin dapat meningkatkan kerentanan terhadap virus. Wanita yang terinfeksi HPV dan paritas tinggi akan memiliki risiko terkena kanker leher rahim yang lebih tinggi dibandingkan dengan wanita yang terinfeksi HPV namun tidak pernah melahirkan. (Iskandar, 2009)

Sumber lain mengemukakan bahwa paritas tinggi merupakan faktor risiko terkena kanker serviks. Melva menyebutkan bahwa golongan wanita yang melahirkan 3 kali atau lebih mempunyai risiko kanker serviks 6 kali lebih besar dari pada golongan wanita bersalin antara 1-3 kali. Meskipun hal ini merupakan faktor risiko namun hal tersebut dapat menjadi perhatian kita untuk mendeteksi terhadap golongan ini. (Putra, 2013).

Hasil penelitian ini menunjukkan bahwa tidak ada hubungan antara paritas dengan kejadian lesi prakanker serviks. Hasil tersebut sama dengan hasil penelitian dari dokter Nindrea (2017) yang menyatakan tidak ada hubungan antara paritas dengan kejadian lesi prakanker serviks, namun hasil ini berbeda dengan hasil penelitian Sinaga (2009) yang menemukan bahwa jumlah anak yang dilahirkan berhubungan kuat dengan lesi prakanker leher rahim, dimana wanita yang memiliki > 2 anak berisiko 2 kali lebih tinggi untuk mengalami kejadian lesi prakanker dibandingkan dengan yang memiliki $\leq 2$ anak. 
Walaupun tidak terdapat hubungan antara paritas dengan kejadian lesi prakanker serviks, saat dilakukan pengelompokkan lagi menjadi perempuan yang memiliki $<2$ anak dan $\geq 2$ anak didapatkan penurunan nilai-p yang sebelumnya 0,63 menjadi 0,28 . Ini menunjukkan tendency atau kecenderungan terdapat hubungan antara lesi prakanker serviks dengan paritas perempuan di Kecamatan Legok.

\section{Aktivitas seksual dengan kejadian lesi prakanker serviks}

Virus HPV merupakan virus yang ditransmisikan melalui hubungan seksual. Dalam penelitian ini aktivitas seksual dikelompokkan berdasarkan pasangan yang melakukan hubungan seksual $\leq$ 7 hari dan yang $>7$ hari. Hasil penelitian ini menemukan bahwa tidak ada hubungan secara statistik antara frekuensi aktivitas seksual dengan kejadian lesi prakanker serviks. Meskipun tidak ada hubungan, tetapi terdapat OR signifikan pada perempuan yang melakukan hubungan seksual dengan pasangannya tiap $\leq 7$ hari memiliki 1,4 risiko untuk mengalami kejadian lesi prakanker dengan wanita yang melakukan hubungan seksual $>7$ hari.

Selain itu, jumlah pasangan seks berkaitan erat dengan kejadian lesi prakanker serviks. Meskipun hampir semua responden hanya memiliki satu pasangan dalam hidup mereka. Semakin muda seorang wanita mulai berhubungan seks, semakin banyak pula pasangan seks yang pernah ia miliki, maka semakin tinggi pula risikonya untuk terinfeksi HPV dan terkena kanker serviks. ${ }^{12}$

Perempuan yang mempunyai banyak pasangan seksual mempunyai risiko lebih besar untuk terkena kanker serviks. Keterlibatan peranan pria terlihat dari adanya kolerasi antara kejadian kanker serviks dengan kanker penis di wilayah tertentu. Lebih jauh meningkatnya kejadian tumor pada wanita monogami yang suaminya sering berhubungan seksual dengan banyak wanita lain menimbulkan konsep "Pria Berisiko Tinggi" sebagai vektor dari agen yang dapat menimbulkan infeksi. (Nelli, 2017)

Banyak penyebab yang dapat menimbulkan kanker serviks, tetapi penyakit ini sebaiknya digolongkan ke dalam penyakit akibat hubungan seksual (PHS). Penyakit kelamin dan keganasan serviks keduanya saling berkaitan secara bebas dan diduga terdapat korelasi nonkausal antara beberapa penyakit akibat hubungan seksual dengan kanker serviks. (Nelli, 2017)

Berdasarkan hasil penelitian dari Susanti (2010) menemukan bahwa jumlah pasangan seks berhubungan erat dengan kejadian lesi prakanker leher rahim, dimana wanita yang memiliki pasangan seks $>1$ orang berisiko 3,8 kali lebih tinggi untuk mengalami lesi prakanker dibandingkan dengan wanita yang memiliki hanya 1 pasangan seks. Sedangkan pada penelitian Wahyuningsih dan Mulyani (2014) tidak ada hubungan antara perilaku seksual (pasangan > 1) dengan kejadian lesi prakanker serviks, meskipun ada kecenderungan risiko 6,19 kali lebih besar pada responden yang memiliki pasangan seks > 1. (Lestari, 2016)

\section{Pendidikan dengan kejadian lesi prakanker serviks}

Menurut hasil penelitian Parikh et al (dalam Iskandar, 2009), risiko kanker leher rahim berhubungan dengan tingkat sosio-ekonomi rendah, yang diukur dari tingkat pendidikan atau tingkat pendapatan. Hubungan tersebut diperkirakan berkaitan dengan peningkatan prevalens dari faktor-faktor risiko kanker leher rahim lainnya, seperti deteksi dini kanker leher Rahim yang tidak adekuat, paritas tinggi, dan kemungkinan perilaku seksual berisiko tinggi pada wanita dengan tingkat sosio-ekonomi rendah. 
Selain usia tingkat pendidikan merupakan salah satu hal yang menjadi penyebab seseorang tidak mengakses pelayanan kesehatan. Pada penelitian yang dilakukan Chasanah (2017) di Puskesmas Candiroto, responden sebagian besar berpendidikan sekolah dasar yaitu sebesar $38,0 \%$. Hal ini dimungkinkan karena rata - rata penduduk di wilayah kerja Puskesmas Candiroto bermatapencaharian sebagai petani, sehingga mereka menganggap bahwa pendidikan atau bersekolah bukan menjadi hal yang penting. Budaya diwilayah itupun menganggap bahwa dengan bersekolah dasar saja sudah cukup. (Chasanah, 2017)

Tinggi rendahnya pendidikan berkaitan dengan tingkat sosio ekonomi, kehidupan seksual dan kebersihan. Penelitian yang dilakukan Surbakti (2004) pendidikan mempunyai hubungan bermakna dengankejadian kanker serviks $\mathrm{OR}=2,012$ dengan kata lain penderita kanker serviks yang berpendidikan rendah merupakan faktor yang berisiko yang mempengaruhi terjadinya kanker serviks. Wanita yang berpendidikan rendah kurang memperhatikan tentang kesehatan, terutama kesehatan yang ada kaitannya dengan kebersihan alat kelaminnya maka akan memiliki risiko untuk terkena kanker serviks. (Mesalina, 2019)

Penelitian yang dilakukan Rahma dan Prabandari (2012) menyatakan bahwa semakin rendah pendidikan wanita maka semakin rendah juga minat untuk melakukan screening kanker serviks dengan pemeriksaan IVA dan begitu juga sebaliknya. Pada wanita dengan pendidikan tinggi minat untuk melakukan pemeriksaan IVA juga semakin tinggi. (Mesalina, 2019)

Hasil penelitian ini menunjukkan bahwa perempuan yang berpendidikan rendah ( $\leq$ tamat SMP) secara statistik hubungan tingkat pendidikan dan kejadian lesi prakanker tidak bermakna. Hasil tersebut serupa dengan hasil penelitan yang diperoleh Kurniati (2011) di Jakarta Timur bahwa tidak ada hubungan antara pendidikan dengan kejadian lesi prakanker serviks. Namun perempuan yang berpendidikan rendah $(\leq$ tamat SMP) berisiko 1,5 kali lebih tinggi dibandingkan dengan perempuan yang berpendidikan akhir $\geq \mathrm{SMA}$ /sederajat untuk mengalami kejadian lesi prakanker.

\section{Pekerjaan dengan kejadian lesi prakanker serviks}

Pekerjaan adalah aktivitas rutin yang dilakukan subjek penelitian di luar maupun didalam rumah yang menghasilkan manfaat dan imbalan materi. Hasil penelitian ini bahwa hubungan antara pekerjaan dengan kejadian lesi prakanker serviks tidak bermakna dengan nilai- $p>\alpha(1,0)$.

Pekerjaan adalah kebutuhan yang harus dilakukan terutama untuk menunjang kehidupannya dan kehidupan keluarga. Bekerja umumnya merupakan kegiatan yang menyita waktu serta dapat memberikan pengalaman maupun pengetahuan baik secara langsung maupun tidak langsung. Lingkungan pekerjaan dapat membentuk suatu pengetahuan karena adanya saling menukar informasi antara teman-teman di lingkungan kerja (Wawan, 2010).

Hasil tersebut dengan hasil penelitian Susanti (2010), dimana tidak ada hubungan yang bermakna antara pekerjaan dengan kejadian lesi prakanker serviks, dengan nilai OR hanya 0,43 bila dilihat dari odd ratio-nya perempuan yang bekerja cenderung lebih rendah untuk terjadinya lesi prakanker serviks dibandingkan dengan perempuan yang tidak bekerja, karena OR yang didapat 0,43 . Hasil penelitian tersebut menyebutkan baik ibu yang bekerja maupun tidak bekerja sebagian besar tidak melakukan pemeriksaan IVA. Hal ini dapat dipengaruhi oleh banyak hal seperti adanya keterpaparan infomasi dan pengaruh teman yang tidak memeriksakan diri dengan IVA sehingga perempuan tidak melakukan pemeriksaan IVA. Selain itu, status tidak bekerja mempengaruhi kepada tingkat penghasilan sehingga perempuan banyak bergantung secara 
ekonomi dengan suami. Hal ini membatasi ibu untuk melakukan pemeriksaan karena adanya biaya transportasi yang harus disiapkan karena tidak semua fasilitas kesehatan dekat dan mudah dijangkau oleh sasaran. (Wawan, 2010).

\section{KESIMPULAN DAN SARAN}

Setelah dilakukan penelitan dapat disimpulkan bahwa tidak terdapat hubungan antara kejadian lesi prakanker serviks dengan sosiodemografi perempuan di Kecamatan Legok Kabupaten Tangerang tahun 2018 ( $\mathrm{p}<0,05$ ). Khususnya pada hubungan antara paritas dengan kejadian lesi prakanker serviks, saat dilakukan pengelompokkan lagi menjadi perempuan yang memiliki < 2 anak dan $\geq 2$ anak didapatkan penurunan nilai-p yang sebelumnya 0,63 menjadi 0,28 . Ini menunjukkan adanya kecenderungan terdapat hubungan antara lesi prakanker serviks dengan paritas perempuan di Kecamatan Legok. Oleh karenanya, perlu meningkatkan kegiatan penyuluhan dan promosi kesehatan mengenai lesi prakanker serviks dan deteksi dini pada seluruh perempuan di Indonesia.

\section{REFERENSI}

Asyifa, F. (2019). Hubungan antara paritas dan tingkat pendidikan terhadap kejadian kanker serviks. Universitas Muhammadiyah Surakarta, Surakarta.

Chasanah, M, et. al. (2017). Gambaran faktor - faktor kejadian lesi prakanker leher rahim di Puskesmas Candiroto, kabupaten Temanggung. Jurnal Kesehatan Masyarakat, 5(2), 58-63

Iskandar, TM. (2009) Pengelolaan lesi prakanker serviks. Indonesia Journal of Cancer, 3(3), 1102.

Koswara, M. (2016). Faktor Risiko Lesi Prakanker Serviks Berdasarkan Hasil Pap Smear Di Klinik Kespro Yayasan Rama Sesana Periode 2013-2015[thesis]. Universitas Udayana, Denpasar.

Kurniati, K. (2012). Pengaruh penggunaan kontrasepsi terhadap kejadian lesi prakanker leher rahim pada wanita yang melakukan pemeriksaan inspeksi visual dengan asam asetat (iva) di tiga puskesmas di Jakarta Timur tahun 2011[thesis]. Fakultas Kesehatan Masyarakat, Jakarta.

Kusuma, AANJ. (2015). Hubungan infeksi hiv dengan lesi prakanker serviks [thesis]. Denpasar: Bagian Obstetri dan Ginekologi RS Sanglah, Denpasar.

Lestari, ND. (2016). Faktor - faktor yang berhubungan dengan kejadian iva positif pada wanita berusia 30-50 tahun di kabupaten Sukoharjo tahun 2016. Universitas Negeri Semarang, Semarang.

Mesalina, R, et. al. (2019). Sosio demografi perempuan pemanfaatan deteksi dini kanker servik metode iva di Bukittinggi. Jurnal Human Care, 4(2), 64-75

Nelli, E. (2017). Analisis faktor-faktor yang berhubungan dengan kejadian kanker serviks di Rumah Sakit Umum Pusat Fatmawati Jakarta tahun 2010. Seminar Nasional Multi Disiplin Ilmu. 1(2). 483-91

Ningsih, DPS, Pramono, D, Nurdiati, DS. (2017). Faktor-faktor yang berhubungan dengan kejadian kanker serviks di RSUP Dr. Sardjito Yogyakarta. Berita Kedokteran Masyarakat, $3(1), 1-5$

Pusat Data dan Informasi Kementerian Kesehatan RI. Situasi penyakit kanker. Jakarta: Kementerian Kesehatan RI; 2015.

Putra, AGRAM. (2013). Hubungan paritas dan usia perkawinan sebagai faktor risiko lesi prakanker serviks pada ibu pasangan usia subur di wilayah kerja Puskesmas Sukasada II. Universitas Udayana, Denpasar.

Rasjidi, I. (2008). Manual prakanker serviks. CV Agung Seto, Jakarta. 
Susanti, I. (2010). Hubungan usia pertama kali berhubungan seksual dan jumlah pasangan seksual dengan kejadian lesi prakanker leher rahim pada wanita yang melakukan deteksi dini menggunakan metode inspeksi visual dengan asam asetat (iva) di Puskesmas Cikampek, Pedes dan Kota Baru Kabupaten Karawang tahun 2009-2010. Fakultas Kesehatan Masyarakat, Depok.

Susilawati, S. (2012). Peran rumah sakit di DKI Jakarta dalam pencegahan kanker serviks [thesis]. Universitas Indonesia, Jakarta.

Wawan, A. (2010). Teori Dan Pengukuran Pengetahuan, Sikap, dan Perilaku Manusia. Nuha Medika, Yogyakarta. 